\section{P4.06 ECOMAP: AN ALTERNATIVE FOR AN INTERDISCIPLINARY ASSISTANCE}

${ }^{1}$ Ana Amélia Nascimento da Silva Bones, 'Silvio César Cazella, ${ }^{2}$ Luciane Salvalaggio Pires Sebastiany, ${ }^{2}$ Stephanie Marson. ' UFCSPA, Porto Alegre - RS, Brazil; ${ }^{2}$ UFRGS, Porto Alegre - RS, Brazil

\subsection{6/sextrans-2017-053264.503}

Introduction In order to obtain an unified care for the health service user, it is necessary that the caring net can have the distance between the theory and the practice reduced. The working process between the teams should be in harmony to the interdisciplinary mode, so that an individualised assistance plan among the several parts can be agreed. Ecomap is an alternative for the identification of the points in the net that are, directly or indirectly, in contact with the user to be analysed. The present study aims at reflecting on the application of the illustrated instrument Ecomap from a complex case lived by the authors in order to discuss the interdisciplinary working process. Case report involving complex situations like the HIV diagnosis in pregnant homeless women that need intersection and interdisciplinary actions to avoid the vertical HIV contamination.

Methods This study aims to describe the experience of using this instrument in collecting data for a research that involved 12 points of society with a gap HIV pregnant homeless, which used symbolic interactionism and grounded theory as a theoretical-methodological reference framework for understanding these linked points. Ecomap presents the lived relations graphically in the moment that the individual, who should be the main map focus, is being studied.

Results The case was awarded by the vertical transmission committee of Porto Alegre for organising the network in an interdisciplinary way, guaranteeing the welfare of the pregnant and her child. The discussion of possible changes in network, the identification of each point members common and singular characteristics.

Conclusion in the context of the organisation of the primary health care, it is important to count on a graphic tool that shows the patient's information in a practical and summarised way, using the no verbal language and also answering to all net points. Because the interpersonal relationships are unstable, the presented data are in continuous changing, and that is why, Ecomap is considered as a photograph of the studied moment.

\section{P4.07 TALKING GROUPS ABOUT STI/HIV PREVENTION WITH LIBERTY DEPRIVED GIRLS FROM THE CASA FOUNDATION OF THE STATE OF SÃO PAULO}

${ }^{1}$ Analice de Oliveira, ${ }^{2}$ Decio Perroni Ribeiro Filho, ${ }^{2}$ Ana Carolina Carvalho Lutfi, ${ }^{2}$ Cintia Magalhães Neia, ${ }^{3}$ Aline Ferreira, ${ }^{3}$ Micaela Cyrino, ${ }^{4}$ Heloisa Hannada, ${ }^{5}$ Luzia Aparecida, ${ }^{6}$ Ivone de Paula. 'Centro de Referência e Treinamento DST/AIDS, São Paulo - SP, Brazil; ${ }^{2}$ Fundação Casa, São Paulo - SP, Brazil; ${ }^{3}$ Rede Estadual de Jovens Vivendo com HIVIAIDS, São Paulo - SP, Brazil; ${ }^{4}$ Centro de Referência e Treinamento DST/AIDS, São Paulo - SP, Brazil; ${ }^{5}$ Articulação Nacional de Movimentos e Praticas de Educação Popular em Saúde, São Paulo - SP, Brazil; ${ }^{6}$ Centro de Referencia e Treinamento DST/AIDS, São Paulo - SP, Brazil

\subsection{6/sextrans-2017-053264.504}

Introduction In 2016, due to the vulnerability to IST/HIV/ AIDS of young people deprived of their liberty, a partnership was established between the STD/AIDS Referral and Training Centre (CRT-DST/Aids, of the Health Secretariat of the State of São Paulo), the Centre for Socio-educational Assistance to Adolescents (CASA) Foundation and UNICEF with the objective to carry out integrated prevention actions with the employees of the Foundation and with the youngsters.

Methods The actions included training, reflections, improvement of STI approaches and treatment with emphasis on syphilis, and access to prevention inputs (male and female condoms and HIV, syphilis, hepatitis B and C testing). A workshop was held with the employees of the Ruth Pistori Women's Unit with the participation of the State Network of Young People Living with HIV/AIDS and representatives of the state in the Health Popular Education Movement. The aim was that the script of the talks were prepared by the staff of the CASA Foundation under the supervision of technicians of the STD/Aids State Program and that they apply to the unit every fortnight so that all the girls could have access to the information and thoughts about combined prevention.

Results In October 2016, were held five Talking Groups with the participation of all 75 girls who were at the Centre at that time. The girls have built murals with prevention ways so they are posted in strategic locations and in classrooms. After the reflections, all the girls wanted to carry out the tests for HIV, hepatitis B and C and Syphilis. The Centre is developing Talking Groups with the girls every fortnight.

Conclusion This experience shows that it is possible to carry out continuous prevention actions at the CASA Foundation's deprivation of liberty units and to work with other forms of prevention besides the use of condoms. So, a Prevention Program for Syphilis with a specific protocol for diagnosis and treatment will be elaborate in 2017 in order to be implemented in all CASA Foundation units.

\section{P4.08 SÃO PAULO STATE STRATEGY FOR THE PREVENTION: DISTRIBUTION OF CONDOMS IN THE SCHOOLS}

${ }^{1}$ Analice de Oliveira, ${ }^{2}$ Fabíola Santos Lopes, ${ }^{3}$ Edison Almeida, ${ }^{1}$ Paula Oliveira Sousa, ${ }^{1}$ Ivone de Paula. 'Centro de Referência e Treinamento DSTIAIDS, São Paulo - SP, Brazil; ${ }^{2}$ Centro de Referência e Treinamento DST/AIDS, São Paulo - SP, Brazil; ${ }^{3}$ Fundação para 0 Desenvolvimento da Educação - FDE, São Paulo - SP, Brazil

\subsection{6/sextrans-2017-053264.505}

AIDS cases among young people aged 15 to 24 years have increased in Brazil 21.5\% in recent years. There is a need to strengthen actions to prevent STD/AIDS in schools, especially regarding the distribution of condoms and promotion of reflection related to sexual diversity, homophobia, racism, prejudice, gender equality and sexual and reproductive health. The "Together in Prevention" strategy of the Centre for Reference and Training - STD/AIDS of the Secretary of State for Health of São Paulo in partnership with the Foundation for the Development of Education - FDE and the Secretariat of Education of the State of São Paulo, was based on the Municipality of Itaquaquecetuba/SP, which, through the involvement of primary health care and the activities of community health agents, expanded prevention actions in the community, implementing Prevention Stations at the meeting points of vulnerable populations for HIV and organised a flow of Condom distribution both at school and elsewhere in the community. Through the articulation of actions with the Association of Parents and Teachers - APM and the School Council, and the youth participation through the Student Councils and the involvement of the parents, the condom entered the school environment consistently. The strategy details 
the step-by-step articulation of public health and education policies in the school space, an action already foreseen in the federal government's "Prevention Is Also Teached" programs, and "Health in School - PSE" In the joint state resolution of SES/SEE that provides for STD/AIDS prevention actions and definition of the transfer of condoms to schools. Experience shows us that it is possible to distribute condoms in schools on an ongoing basis, and it is fundamental to articulate the school/basic health unit.

\section{P4.09 BRAZILIAN MULTICENTRIC CAMPAIGN ON HIVIAIDS}

Andrey Oliveira da Cruz, Bruna Kariny de Oliveira Pereira. International Federation of Medical Students' Associations of Brazil, São Paulo - SP, Brazil

\subsection{6/sextrans-2017-053264.506}

Introduction HIV and AIDS represent one of the greatest concerns in global health in the last three decades. In Brazil, the percentage of people living with HIV and dying with AIDS increases every year. The number of cases in the south of Brazil is bigger than in the rest of the country, particularly in Rio Grande do Sul and Santa Catarina as the second and third states with the largest numbers. Medical students from the International Federation of Medical Students Association of Brazil (IFMSA Brazil) in the south of the country conducted this study to better comprehension of Brazilian citizens' understanding about the subject.

Methods This study investigated the profile of general population in three Brazilian cities (Curitiba, Londrina and Tubarão), identifying the sociodemographic aspects and knowledge level related to HIV and AIDS, in a descriptive and quantitative analysis. Data was collected through a questionnaire with nine questions, in November 2016.

Results 343 individuals, $57 \%$ female and the majority of them between 21 and 30 years old. The answers showed an alarming situation in the south region of Brazil. Almost half of them $(49.6 \%)$ did not know about their serology for HIV, meanwhile $60.6 \%$ revealed already being worried about that. Regarding HIV and AIDS definition, 71.7\% did not know the difference between the virus and the syndrome. When asked about a method of prevention for HIV and other STIs, more than $90 \%$ knew how to prevent themselves and most of them mentioned condoms as the method used. Only $41.4 \%$ reported using condoms regularly. When asked about social interaction with people living with HIV, 74.6\% would not have sexual relations and $16.9 \%$ would not be friends with someone living with the virus.

Conclusion One of the reasons for the massive numbers of HIV cases in the south of Brazil is the lack of knowledge of the population. Knowing the social determinants and population profile allows integrative practices, as the development of new action strategies to improve health promotion and health education regarding HIV and AIDS.

\section{P4.10 IFMSA BRAZIL'S EXPERIENCE ON HEALTH PROMOTION AND EDUCATION IN HIVIAIDS}

Andrey Oliveira da Cruz, Rafael Silveira Batista, Bruna Kariny de Oliveira Pereira. International Federation of Medical Students' Associations of Brazil (IFMSA Brazil), São Paulo - SP, Brazil

10.1136/sextrans-2017-053264.507
Introduction The International Federation of Medical Students' Associations of Brazil (IFMSA Brazil) is a nonprofit, nonpartisan and non-governmental organisation representative of Brazilian medical students. IFMSA Brazil was founded in 1991 and it is currently present in 95 medical schools around the country, at 26 Brazilian states. IFMSA Brazil envisions promoting a positive impact in society by allowing medical students to become leaders in health advocate, to find and to develop their potential. IFMSA Brazil acts through priority areas, defined by Standing Committees, developing projects and programs that may impact on society aiming health promotion and education. The Standing Committee on Sexual and Reproductive Health including HIV/AIDS (SCORA) brings the subject to discussion and engages Brazilian medical students to advocate on this specific field.

Methods We analysed IFMSA Brazil's Online System of Activities and Reports (SOLAR), which archives all projects and activities held by the Federation in its 95 Local Committees. We considered all the post-projects submitted to the platform of SCORA in 2016.

Results We received 108 activities submissions related to HIV, HPV and syphilis. The main activities developed were Candlelight Memorial Day, Health Care Blitzes, "Adolescer" - a Comprehensive Sexual Education Project for Teenagers, Campaigns of Act Against AIDS, Sexual Education Projects directed to elderly and sex workers and general events related to sexual and reproductive health in medical education.

Conclusion Developing new strategies of health promotion and education in sexual and reproductive theme may help different communities and improve education of Brazilian medical students. IFMSA Brazil is acting in a volunteering work to raise medical students' voice and engage advocacy in health, allowing the health care attention to neglected populations and preventing the increase of sexually transmitted infections and other diseases.

\section{P4.11 "I THINK IT HAS BEEN A NEGATIVE INFLUENCE IN MANY WAYS BUT AT THE SAME TIME I CAN'T STOP USING IT": SELF-IDENTIFIED PROBLEMATIC PORNOGRAPHY USE AMONG A SAMPLE OF YOUNG AUSTRALIANS}

${ }^{1}$ Angela Davis, ${ }^{1}$ Elise Carrotte, ${ }^{1}$ Margaret Hellard, ${ }^{2}$ Meredith Temple-Smith, ${ }^{1}$ Megan Lim. ${ }^{1}$ Burnet Institute, Melbourne, Australia; ${ }^{2}$ University of Melbourne, Melbourne, Australia

\subsection{6/sextrans-2017-053264.508}

Introduction Online pornography use among young people has raised concerns over the potential for "pornography addiction". There are no diagnostic criteria for pornography addiction and little is known about young people's experience of this phenomenon. We asked a sample of young Australian's about the influence of pornography on their lives and analysed responses for themes of self-identified problematic consumption.

Methods Participants $(n=1029)$ aged 15-29 years were recruited via Facebook to an online survey. Those who had ever viewed pornography $(n=856)$ were asked in an openended question: 'How has pornography influenced your life?'. Data were thematically analysed for sentiment and theme. Sub-themes were developed for responses, which indicated problematic usage including obsessive thoughts, compulsive 